\title{
Protection of the Liver by Ischemic Preconditioning: A Review of Mechanisms and Clinical Applications
}

\author{
Rahul S. Koti Alexander M. Seifalian Brian R. Davidson \\ University Department of Surgery and Liver Transplantation Unit, Royal Free and University College \\ Medical School, University College London and Royal Free Hospital NHS Trust, London, UK
}

\section{Key Words}

Liver · Preconditioning · Ischemia · Reperfusion •

Liver injury · Hepatoprotection • Liver transplantation •

Liver resection - Nitric oxide · Adenosine .

Heat shock proteins - Protein kinase C review assesses possible mechanisms of ischemic preconditioning and its role in hepatic surgery and liver transplantation. The future lies in defining the mechanisms of the ischemic preconditioning effect to allow drug targeting to induce the preconditioning response.

Copyright $\odot 2003$ S. Karger AG, Basel

\begin{abstract}
Ischemic preconditioning refers to the endogenous mechanism of protection against a sustained ischemic insult following an initial, brief ischemic stimulus. Ischemia-reperfusion injury of the liver is a major cause of morbidity and mortality in liver surgery and transplantation and ischemic preconditioning is a promising strategy for improving the outcome of liver surgery. The preconditioning phenomenon was first described in a canine model of myocardial ischemia-reperfusion injury in 1986 and since then has been shown to exist in other organs including skeletal muscle, brain, kidneys, retina and liver. In the liver, the preconditioning effect has been demonstrated in rodents and a recent study has demonstrated human clinical benefits of preconditioning during hemihepatectomies. Ischemic preconditioning has been described as an adaptive response and although the precise mechanism of hepatoprotection from preconditioning is unknown it is likely to be a receptor-mediated process. Several hypotheses have been proposed and this
\end{abstract}

\section{Introduction}

Ischemia-reperfusion injury is a major cause of morbidity and mortality following liver surgery and transplantation. Ischemia-reperfusion injury after prolonged ischemia has been shown to occur in virtually all organ systems. Ischemic (and reperfusion) injury to the liver occurs during liver resections performed under temporary inflow occlusion (Pringle manoeuvre) or inflow and outflow occlusion commonly used to reduce intraoperative blood loss, and during storage and implantation of livers for transplantation. The liver tolerates prolonged ischemia poorly and safe ischemic times particularly for the diseased liver are not known. Both warm and cold ischemias result in significant liver injury [1], and ischemia reperfusion injury of the liver can result in multiple system organ failure and systemic inflammatory response syndrome (fig. 1).

\begin{tabular}{ll}
\hline KARGER & ( ) 2003 S. Karger AG, Basel \\
0253-4886/03/0205-0383\$19.50/0 \\
$\begin{array}{l}\text { Fax +4161306 1234 } \\
\begin{array}{l}\text { E-Mail karger@karger.ch } \\
\text { www.karger.com }\end{array}\end{array}$ & $\begin{array}{l}\text { Accessible online at: } \\
\text { www.karger.com/dsu }\end{array}$
\end{tabular}

Brian R. Davidson, Professor of Surgery and Liver Transplantation University Department of Surgery and Liver Transplantation Unit Royal Free and University College Medical School

Royal Free Hospital, Pond Street, London NW3 2QG (UK)

Tel. +44 207830 2757, Fax +44207830 2688, E-Mail b.davidson@rfc.ucl.ac.uk 


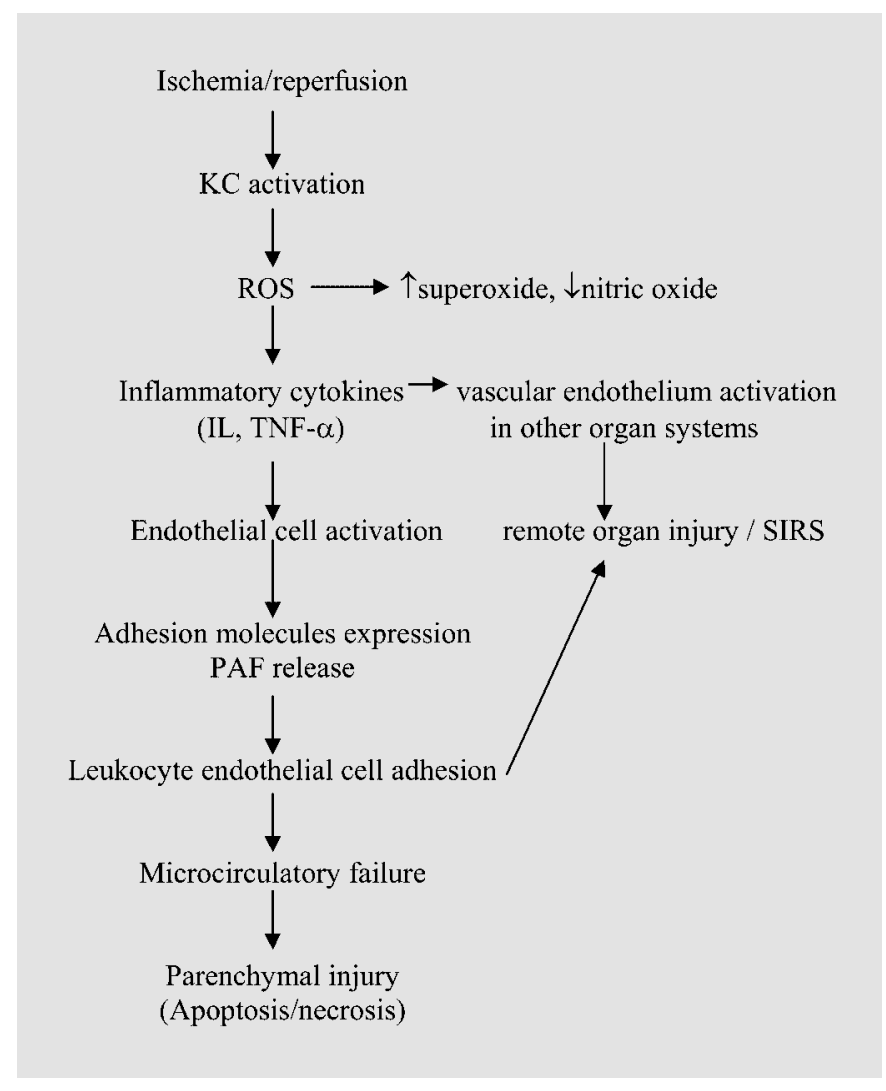

Fig. 1. Schematic illustration of pathophysiological events following reperfusion of ischemic liver. $\mathrm{ROS}=$ Reactive oxygen species; $\mathrm{IL}=$ interleukin; $\mathrm{PAF}=$ platelet-activating factor; $\mathrm{SIRS}=$ systemic inflammatory response syndrome.

Brief episodes of ischemia followed by a period of reperfusion called ischemic preconditioning (IPC) have been shown to protect organs against subsequent sustained ischemia. IPC was first described by Murry et al. [2] in 1986. In a canine model, they demonstrated that multiple brief ischemic episodes protected the heart from a subsequent sustained ischemic insult. Since then myocardial IPC has been shown to occur in many animal species [3] and in humans [4]. Subsequently, IPC has been demonstrated in other organ systems including skeletal muscle [5], brain [6], spinal cord [7], kidney [8], intestine [9] and liver [10]. Although these studies suggested a preconditioning response in most organ systems the mechanism of the preconditioning effect remains uncertain.

IPC has been described as an endogenous adaptive mechanism for prevention of injury resulting from ischemia reperfusion [2]. The phenomenon is fascinating, as it is easily reproducible and potentially readily applicable in clinical situations. In the liver the preconditioning effect is a promising strategy in assisting preservation of the liver in clinical situations of anticipated hepatic ischemia such as transplantation and during resection for tumors using hepatic vascular occlusion. Increase in ischemic hepatic tissue tolerance may protect against ischemiareperfusion injury and assist preservation of livers for transplantation as well improve outcome after surgical procedures. Clearly, identifying the mechanism of preconditioning may allow recognition of a pharmacological agent, to protect the liver from ischemic injury.

The mechanisms underlying the preconditioning effect have not been defined. In contrast, various potential mediators have been proposed and investigated. Most of the data on mediators of preconditioning in organs including the liver has been extrapolated from information gathered in the heart. This article reviews the major developments in characterization of mechanisms of IPC in the liver. In addition, clinical applications of IPC to minimize ischemic injury to the liver have been discussed.

\section{Methods of Search}

All the studies were identified by PubMed, ISIS and CAS searches between the years 1966 and September 2002 with the following key words: ischemia, ischemiareperfusion injury, preconditioning, IPC, hepatoprotection. Other sources include review articles and textbooks.

\section{Evidence that IPC Occurs in the Liver}

\section{Studies on Warm Ischemia}

Over the last decade many investigators have studied the effects of IPC on regional and global ischemia in the liver, and the evidence is encouraging (see table 1). LlorisCarsi et al. [10] in 1993 first demonstrated in the rat liver that a single episode of preconditioning with 5 min portal triad clamping followed by $10 \mathrm{~min}$ reperfusion showed improved survival and decreased liver enzyme levels after subsequent $90 \mathrm{~min}$ ischemia. Hardy et al. [11] showed improved survival in rats undergoing liver resection during $45 \mathrm{~min}$ ischemia after prior $5 \mathrm{~min}$ ischemia with 10 min reperfusion. Similarly Yoshizumi et al. [12] have demonstrated improved survival and increased tissue ATP with preconditioning in a rat liver resection model. Subsequently the IPC effect in the liver has been reproduced in several in vivo rodent models of partial and global liver ischemia [13-38]. These studies have demonstrated that liver IPC for warm ischemia resulted in 
Table 1. Current data on hepatic IPC: published studies

\begin{tabular}{|c|c|c|c|c|c|c|c|c|c|c|}
\hline $\begin{array}{l}\text { Study } \\
\text { group }\end{array}$ & Year & Species & $\begin{array}{l}\text { IPC time } \\
\text { min }\end{array}$ & $\begin{array}{l}\text { Ischemia } \\
\text { time } \\
\text { min }\end{array}$ & $\begin{array}{l}\text { Reper- } \\
\text { fusion } \\
\text { time, min }\end{array}$ & $\begin{array}{l}\text { Hepatic } \\
\text { ischemia }\end{array}$ & $\begin{array}{l}\text { Pharmacological } \\
\text { manipulations }\end{array}$ & Parameters assessed & Outcome of IPC & $\begin{array}{l}\text { Proposed } \\
\text { mechanism }\end{array}$ \\
\hline $\begin{array}{l}\text { Lloris-Carsi } \\
\text { et al. [10] }\end{array}$ & 1993 & Rat & $\begin{array}{l}1 \times 3 \\
(5 \mathrm{I}+10 \mathrm{R})\end{array}$ & 90 & 3 days & Total & Nil & LFTs and survival & $\begin{array}{l}70 \% 3 \text { day survival }+ \\
\downarrow \text { liver enzyme levels }\end{array}$ & Not addressed \\
\hline $\begin{array}{l}\text { Hardy } \\
\text { et al. [11] }\end{array}$ & 1996 & Rat & $5 \mathrm{I}+10 \mathrm{R}$ & $0-45$ & $1-8$ days & Partial & Nil & $\begin{array}{l}\text { LFTs, histology } \\
\text { and survival }\end{array}$ & $\begin{array}{l}90 \% 1 \text { day survival, } \\
\uparrow \text { prothrombin time }\end{array}$ & Not addressed \\
\hline $\begin{array}{l}\text { Peralta } \\
\text { et al. [13] }\end{array}$ & 1996 & Rat & $10 \mathrm{I}+10 \mathrm{R}$ & 90 & 90 & Partial & $\begin{array}{l}\text { Spermine NONOate, } \\
L \text {-NAME/bosentan }\end{array}$ & $\begin{array}{l}\text { LFTs, tissue endothelin } \\
\text { and NOS activity, histology }\end{array}$ & $\begin{array}{l}\downarrow \text { GPT and } \\
\text { endothelin } \uparrow \text { cNOS }\end{array}$ & NO \\
\hline $\begin{array}{l}\text { Kume } \\
\text { et al. [29] }\end{array}$ & 1996 & Rat & $15 \mathrm{I}$ & 30 & 10 and 40 & Total & $\begin{array}{l}\text { Hyperthermia: } 42^{\circ} \mathrm{C} \\
\text { for } 15 \mathrm{~min}\end{array}$ & $\begin{array}{l}\text { ATP, transaminase, } \\
\text { LDH, HSP72, survival }\end{array}$ & $\begin{array}{l}100 \% \text { survival, } \uparrow \text { ATP, } \\
\downarrow \text { transaminase and LDH }\end{array}$ & HSP72 \\
\hline $\begin{array}{l}\text { Peralta } \\
\text { et al. [17] }\end{array}$ & 1997 & Rat & $10 \mathrm{I}+10 \mathrm{R}$ & 90 & 90 & Partial & $\begin{array}{l}\text { Spermine NONOate; } \\
\text { adenosine; } L \text {-NAME }\end{array}$ & LFTs, HM & $\downarrow$ transaminases and LDH & $\begin{array}{l}\text { Adenosine } \\
\text { and NO }\end{array}$ \\
\hline $\begin{array}{l}\text { Peralta } \\
\text { et al. [18] }\end{array}$ & 1998 & Rat & $2-30 I+10 R$ & 90 & 90 & Partial & $\begin{array}{l}\text { Adenosine deaminase/ } \\
\text { xanthine; spermine } \\
\text { NONOate }\end{array}$ & LFTs & $\downarrow$ transaminases & $\begin{array}{l}\text { Adenosine } \\
\text { and NO }\end{array}$ \\
\hline $\begin{array}{l}\text { Yoshizumi } \\
\text { et al. [12] }\end{array}$ & 1998 & Rat & $5 \mathrm{I}+10 \mathrm{R}$ & 40 & 120 & Partial & Nil & $\begin{array}{l}\text { LFTs, bile flow, } \\
\text { tissue ATP, histology }\end{array}$ & $\begin{array}{l}\downarrow \text { transaminase, } \mathrm{LDH} \text { and } \\
\text { tissue necrosis, } \uparrow \text { ATP }\end{array}$ & Not addressed \\
\hline $\begin{array}{l}\text { Yin } \\
\text { et al. [26] }\end{array}$ & 1998 & Rat & $\begin{array}{l}5 \mathrm{I}, 10 \mathrm{I} \text { or } \\
20 \mathrm{I}+10 \mathrm{R}\end{array}$ & $16-24 h^{a}$ & $\begin{array}{l}60 \text { min } \\
\text { to } 5 \text { days }\end{array}$ & $\begin{array}{l}\text { Cold } \\
\text { storage }\end{array}$ & $\begin{array}{l}L \text {-arginine/adenosine; } \\
L \text {-NAME }\end{array}$ & $\begin{array}{l}\text { LFTs, bile flow, } \\
\text { TNF- } \alpha \text {, survival }\end{array}$ & $\begin{array}{l}87.5 \% 1 \text { day and } \\
75 \% 5 \text { days graft survival }\end{array}$ & NO \\
\hline $\begin{array}{l}\text { Adam } \\
\text { et al. [57] }\end{array}$ & 1998 & Rat & $\begin{array}{l}5 \text { or } \\
10 I+10 R\end{array}$ & $24 \mathrm{~h}^{\mathrm{a}}$ & 180 & $\begin{array}{l}\text { Cold } \\
\text { storage (UW) }\end{array}$ & Nil & $\begin{array}{l}\text { Bile, transaminases, } \mathrm{LDH} \\
\text { release, vascular resistance }\end{array}$ & $\begin{array}{l}\uparrow \text { transaminases, } \mathrm{LDH} \\
\text { and vascular resistance }\end{array}$ & Not addressed \\
\hline $\begin{array}{l}\text { Peralta } \\
\text { et al. [19] }\end{array}$ & 1999 & Rat & $10 \mathrm{I}+10 \mathrm{R}$ & 90 & 90 & Partial & $\begin{array}{l}\text { Adenosine; adenosine } \\
\text { deaminase; DPCPX; } \\
\text { DMPX }\end{array}$ & $\begin{array}{l}\text { Transaminases, hepatic } \\
\text { perfusion, nitrite/nitrates }\end{array}$ & $\begin{array}{l}\text { Adenosine } \mathrm{A} 2 \text { receptor } \\
\text { antagonist abolished }\end{array}$ & $\begin{array}{l}\text { Adenosine } \mathrm{A} 2 \\
\text { receptors and NO }\end{array}$ \\
\hline $\begin{array}{l}\text { Peralta } \\
\text { et al. [20] }\end{array}$ & 1999 & Rat & $10 \mathrm{I}+10 \mathrm{R}$ & 90 & 90 & Partial & $\begin{array}{l}\text { Gadolinium chloride, } \\
\text { TNF, } L \text {-NAME, } \\
\text { spermine NONOate }\end{array}$ & $\begin{array}{l}\text { TNF, transaminases, } \\
\text { vascular permeability, } \\
\text { edema, MPO, histology }\end{array}$ & $\downarrow \mathrm{TNF}$ and tissue injury & $\mathrm{NO}$ \\
\hline $\begin{array}{l}\text { Yadav } \\
\text { et al. [27] }\end{array}$ & 1999 & Mouse & $10 \mathrm{I}+10 \mathrm{R}$ & $75-90$ & $60-180$ & $\begin{array}{l}\text { Partial } \\
\text { and total }\end{array}$ & Nil & $\begin{array}{l}\text { LFTs, hepatocellular } \\
\text { apoptosis, survival }\end{array}$ & $\begin{array}{l}\downarrow \text { apoptosis of } \\
\text { hepatocytes and SEC }\end{array}$ & $\begin{array}{l}\text { Modulation of } \\
\text { apoptosis cascade }\end{array}$ \\
\hline $\begin{array}{l}\text { Nakayama } \\
\text { et al. [28] }\end{array}$ & 1999 & Rat & $10 \mathrm{I}+10 \mathrm{R}$ & 45 & $\begin{array}{l}40 \mathrm{~min} \\
\text { to } 24 \mathrm{~h}\end{array}$ & Total & $\begin{array}{l}\text { AdoR A1, A2 agonists } \\
\text { and antagonists }\end{array}$ & $\begin{array}{l}\text { LFTs, tissue ATP, } \\
\text { histology, survival }\end{array}$ & $\begin{array}{l}\uparrow \text { adenosine } \\
\downarrow \text { tissue damage }\end{array}$ & $\begin{array}{l}\text { Adenosine A2 } \\
\text { receptors }\end{array}$ \\
\hline $\begin{array}{l}\text { Zapletal } \\
\text { et al. [40] }\end{array}$ & 1999 & Rat & $5 \mathrm{I}+10 \mathrm{R}$ & 70 & 30 & Partial & Nil & Intravital microscopy & $\begin{array}{l}\uparrow \text { perfusion parameters, } \\
\downarrow \text { leucocyte adherence }\end{array}$ & \\
\hline $\begin{array}{l}\text { Nilsson } \\
\text { et al. [24] }\end{array}$ & 2000 & Rat & $10 \mathrm{I}+15 \mathrm{R}$ & 60 & 60 & Total & Dipyridamole & LFTs, HM & $\begin{array}{l}\uparrow \text { peripheral liver blood } \\
\text { flow and } \downarrow \text { transaminase }\end{array}$ & Adenosine \\
\hline $\begin{array}{l}\text { Howell } \\
\text { et al. [25] }\end{array}$ & 2000 & Mouse & $5 I+10 R$ & 30 & $\begin{array}{l}30 \mathrm{~min} \\
\text { to } 24 \mathrm{~h}\end{array}$ & Partial & Dipyridamole & $\begin{array}{l}\text { LFTs, leukocyte/ } \\
\text { endothelial cell adhesion }\end{array}$ & $\begin{array}{l}\downarrow \text { endothelial/leukocyte in- } \\
\text { teraction and transaminase }\end{array}$ & Adenosine \\
\hline $\begin{array}{l}\text { Clavien } \\
\text { et al. [43] }\end{array}$ & 2000 & Human & $10 \mathrm{I}+10 \mathrm{R}$ & 30 & 30 & Total & Nil & $\begin{array}{l}\text { LFTs, hepatocellular } \\
\text { apoptosis }\end{array}$ & $\begin{array}{l}\downarrow \text { transaminases and } \\
\text { apoptotic sinusoidal } \\
\text { lining cells }\end{array}$ & $\begin{array}{l}\text { Modulation of } \\
\text { apoptosis cascade }\end{array}$ \\
\hline $\begin{array}{l}\text { Peralta } \\
\text { et al. [21] }\end{array}$ & 2000 & Rat & $10 \mathrm{I}+10 \mathrm{R}$ & $10-90$ & 90 & Partial & SQ-22536, forskolin & $\begin{array}{l}\text { Adenine nucleotides, gly- } \\
\text { cogen, glucose-6-P, fruc- } \\
\text { tose-6-P, transaminases }\end{array}$ & $\begin{array}{l}\text { Preserved energy metabo- } \\
\text { lism during sustained } \\
\text { ischemia }\end{array}$ & $\begin{array}{l}\text { cAMP dependent } \\
\text { PKC }\end{array}$ \\
\hline $\begin{array}{l}\text { Tsumaya } \\
\text { et al. [31] }\end{array}$ & 2000 & Mice & $\begin{array}{l}10 / 15 / \\
20 \mathrm{I}+20 \mathrm{R}\end{array}$ & 70 & $1-48 \mathrm{~h}$ & Total & Nil & $\begin{array}{l}\text { TNF, IL-6, transaminase, } \\
\text { histology, survival }\end{array}$ & $\begin{array}{l}\uparrow \text { survival, } \\
\downarrow \text { transaminase, TNF, } \\
\text { IL-6 and liver necrosis }\end{array}$ & Not addressed \\
\hline $\begin{array}{l}\text { Peralta } \\
\text { et al. [22] }\end{array}$ & 2001 & Rat & $10 \mathrm{I}+10 \mathrm{R}$ & 90 & $0-360$ & Partial & $\begin{array}{l}\text { AICAR/8-bromo-AMP/ } \\
\text { araA; ZVAD; spermine } \\
\text { NONOate/ L-NAME }\end{array}$ & $\begin{array}{l}\text { AMPK activity, nucleotides, } \\
\text { lactate, transaminases, } \\
\text { apoptosis, histology }\end{array}$ & $\begin{array}{l}\text { AMPK activation, } \uparrow \text { ATP, } \\
\downarrow \text { lactate and hepatic injury }\end{array}$ & AMP via PKC \\
\hline $\begin{array}{l}\text { Peralta } \\
\text { et al. [23] }\end{array}$ & 2001 & Rat & $10 \mathrm{I}+10 \mathrm{R}$ & 90 & 90 & Partial & $\begin{array}{l}\text { ICAM, P-selectin } \\
\text { and TNF blockade; } \\
\text { TNF/gadolinium }\end{array}$ & $\begin{array}{l}\text { MPO and lipid peroxida- } \\
\text { tion, vascular permeability, } \\
\text { TNF, transaminases, hepatic } \\
\text { perfusion, histology, ICAM } \\
\text { and P-selectin expression }\end{array}$ & $\begin{array}{l}\text { Remote organ protection } \\
\text { by hepatic preconditioning }\end{array}$ & $\begin{array}{l}\text { TNF and } \\
\text { P-selectin }\end{array}$ \\
\hline $\begin{array}{l}\text { Schulz } \\
\text { et al. [58] }\end{array}$ & 2001 & Pig & $\begin{array}{l}10 \mathrm{I}+10 \mathrm{R} \\
\times 3\end{array}$ & $120-200$ & 480 or 300 & Total & Nil & $\begin{array}{l}\text { ICG clearance, bile flow, } \\
\text { transaminases, ATP, gly- } \\
\text { cogen and lactate contents, } \\
\text { histology }\end{array}$ & $\begin{array}{l}\text { No protection against } \\
\text { prolonged ischemia }\end{array}$ & Not addressed \\
\hline
\end{tabular}


Table 1 (continued)

\begin{tabular}{|c|c|c|c|c|c|c|c|c|c|c|}
\hline $\begin{array}{l}\text { Study } \\
\text { group }\end{array}$ & Year & Species & $\begin{array}{l}\text { IPC time } \\
\text { min }\end{array}$ & $\begin{array}{l}\text { Ischemia } \\
\text { time } \\
\text { min }\end{array}$ & $\begin{array}{l}\text { Reper- } \\
\text { fusion } \\
\text { time, min }\end{array}$ & $\begin{array}{l}\text { Hepatic } \\
\text { ischemia }\end{array}$ & $\begin{array}{l}\text { Pharmacological } \\
\text { manipulations }\end{array}$ & Parameters assessed & Outcome of IPC & $\begin{array}{l}\text { Proposed } \\
\text { mechanism }\end{array}$ \\
\hline $\begin{array}{l}\text { Arai } \\
\text { et al. [51] }\end{array}$ & 2001 & Rat & $\begin{array}{l}5 \text { or } \\
10 \mathrm{I}+10 \mathrm{R}\end{array}$ & $30 \mathrm{~h}^{\mathrm{a}}$ & 15 or 240 & $\begin{array}{l}\text { Cold } \\
\text { storage }\end{array}$ & Nil & $\begin{array}{l}\text { SEC injury, superoxide } \\
\text { formation in Kupffer cells, } \\
\text { graft survival and TNF } \\
\text { after OLT }\end{array}$ & $\begin{array}{l}\uparrow \text { graft survival and } \\
\text { protection contralateral } \\
\text { liver }\end{array}$ & Not addressed \\
\hline $\begin{array}{l}\text { Ricciardi } \\
\text { et al. [52] }\end{array}$ & 2001 & Pig & $15 I+15 R$ & $120^{\mathrm{a}}$ & 240 & $\begin{array}{l}\text { Cold } \\
\text { storage }\end{array}$ & $\begin{array}{l}\text { PKC inhibitor } \\
\text { chelerythrine }\end{array}$ & $\begin{array}{l}\text { Graft function and circula- } \\
\text { tion, LDH, endothelial cell } \\
\text { damage, PKC levels }\end{array}$ & $\uparrow$ graft function & PKC \\
\hline $\begin{array}{l}\text { Ricciardi } \\
\text { et al. [53] }\end{array}$ & 2001 & Pig & $15 \mathrm{I}+15 \mathrm{R}$ & $120^{\mathrm{a}}$ & 240 & $\begin{array}{l}\text { Cold } \\
\text { storage }\end{array}$ & $\begin{array}{l}\text { Tyrosine kinase } \\
\text { inhibitor, genistein }\end{array}$ & $\begin{array}{l}\text { graft function and circula- } \\
\text { tion, Tyrosine kinase } \\
\text { activity }\end{array}$ & $\uparrow$ graft function & Tyrosine kinases \\
\hline $\begin{array}{l}\text { Saito } \\
\text { et al. [33] }\end{array}$ & 2001 & Rat & $10 \mathrm{I}+10 \mathrm{R}$ & 40 & $6-48 \mathrm{~h}$ & Partial & Nil & $\begin{array}{l}\text { Transaminases, endothelial } \\
\text { cell injury, apoptosis, } \\
\text { transcription of IEG's }\end{array}$ & $\begin{array}{l}\downarrow \text { transaminases, endo- } \\
\text { thelial cell injury, necrosis, } \\
\text { apoptosis and IEG tran- } \\
\text { scription }\end{array}$ & Not addressed \\
\hline $\begin{array}{l}\text { Yamada } \\
\text { et al. [32] }\end{array}$ & 2001 & Rat & $10 \mathrm{I}+10 \mathrm{R}$ & $40-120$ & $\begin{array}{l}\text { Up to } \\
7 \text { days }\end{array}$ & Partial & Nil & $\begin{array}{l}\text { Transaminases, LDH, } \\
\text { necrosis, hepatocyte } \\
\text { regeneration }\end{array}$ & $\begin{array}{l}\downarrow \text { transaminases, } \\
\text { LDH and necrosis }\end{array}$ & Not addressed \\
\hline $\begin{array}{l}\text { Zhang } \\
\text { et al. [34] }\end{array}$ & 2001 & Mice & & & & & Nil & $\begin{array}{l}\text { Transaminase, LDH, } \\
\text { LPO, SOD }\end{array}$ & $\begin{array}{l}\downarrow \text { transaminases, LDH, } \\
\mathrm{LPO} \text { and } \uparrow \mathrm{SOD}\end{array}$ & Not addressed \\
\hline $\begin{array}{l}\text { Ishii } \\
\text { et al. [39] }\end{array}$ & 2001 & Rat & $10 \mathrm{I}+10 \mathrm{R}$ & 40 & $6-48 \mathrm{~h}$ & & Nil & $\begin{array}{l}\text { Transaminases, LDH, } \\
\text { necrosis, apoptosis, IEG } \\
\text { transcription alterations }\end{array}$ & $\begin{array}{l}\downarrow \text { transaminases, LDH, } \\
\text { necrosis, apoptosis, IEG } \\
\text { transcription alterations }\end{array}$ & Not addressed \\
\hline $\begin{array}{l}\text { Peralta } \\
\text { et al. [35] }\end{array}$ & 2002 & Rat & $10 \mathrm{I}+10 \mathrm{R}$ & 90 & 90 & Partial & $\begin{array}{l}\text { Xanthine, xanthine } \\
\text { oxidase, allopurinol, } \\
\text { GSH ester }\end{array}$ & $\begin{array}{l}\text { Xanthine, glutathione, } \\
\text { superoxide dismutase, } \\
\text { lipid peroxidation, } \\
\text { transaminases }\end{array}$ & $\begin{array}{l}\downarrow \text { xanthine, XOD in liver } \\
\text { with } \downarrow \text { neutrophil accumu- } \\
\text { lation, oxidative stress, } \\
\text { and microvascular } \\
\text { disorders in lung }\end{array}$ & $\begin{array}{l}\text { Xanthine/XOD } \\
\text { pathway for ROS } \\
\text { generation }\end{array}$ \\
\hline $\begin{array}{l}\text { Sindram } \\
\text { et al. [50] }\end{array}$ & 2002 & Rat & $10 I+15 R$ & $30 \mathrm{~h}^{\mathrm{a}}$ & 60 & $\begin{array}{l}\text { Cold } \\
\text { storage (UW) }\end{array}$ & $\mathrm{N}$-acetyl-cysteine & $\begin{array}{l}\text { SEC detachment, apoptosis, } \\
\text { peroxide, gelatinolytic and } \\
\text { gelatinase activity }\end{array}$ & $\begin{array}{l}\downarrow \text { SEC detachment and } \\
\text { activities of matrix } \\
\text { metalloproteinase }\end{array}$ & $\begin{array}{l}\text { Oxygen free } \\
\text { radicals }\end{array}$ \\
\hline $\begin{array}{l}\text { Rudiger } \\
\text { et al. [36] }\end{array}$ & 2002 & Mice & $10 \mathrm{I}+15 \mathrm{R}$ & $75-120$ & 180 & Partial & Nil & $\begin{array}{l}\text { Transaminase, apoptosis } \\
\text { markers, histology, } \\
\text { survival }\end{array}$ & $\begin{array}{l}\downarrow \text { transaminase, no apop- } \\
\text { tosis or necrosis, } 100 \% \\
\text { survival for ischemic } \\
\text { period up to } 75 \text { min but } \\
\text { not } 120 \text { min }\end{array}$ & $\begin{array}{l}\text { Modulation of } \\
\text { apoptosis cascade }\end{array}$ \\
\hline $\begin{array}{l}\text { Ajamieh } \\
\text { et al. [37] }\end{array}$ & 2002 & Rat & $10 \mathrm{I}+10 \mathrm{R}$ & 90 & 90 & Partial & Ozone & $\begin{array}{l}\text { Transaminases, } 5^{\prime}-\mathrm{NT} \text {, } \\
\text { oxidative stress, histology }\end{array}$ & $\begin{array}{l}\downarrow \text { hepatocellular injury } \\
\text { and oxidative stress }\end{array}$ & Not addressed \\
\hline $\begin{array}{l}\text { Peralta } \\
\text { et al. [14] }\end{array}$ & 2002 & Mice & $10 I+15 R$ & 90 & $6-24 \mathrm{~h}$ & Partial & $\begin{array}{l}\text { Gadolinium chloride, } \\
\text { TNF, MIP-2, } \\
\text { antibodies against } \\
\text { TNF and MIP-2 }\end{array}$ & $\begin{array}{l}\text { Transaminases, TNF, } \\
\text { MIP-2, MDA, MPO, } \\
\text { P-selectin expression }\end{array}$ & $\begin{array}{l}\text { Preconditioning and } \mathrm{Bcl}-2 \\
\text { overexpression together } \\
\text { abolished liver injury }\end{array}$ & $\begin{array}{l}\text { Via TNF and } \\
\text { MIP-2 inhibition }\end{array}$ \\
\hline $\begin{array}{l}\text { Serafin } \\
\text { et al. [47] }\end{array}$ & 2002 & Rat & $\begin{array}{l}10 I+10 R \\
10 I+15 R \text { or } \\
5 I+10 R\end{array}$ & 60 & $2-24 \mathrm{~h}$ & Partial & $\begin{array}{l}\text { NO donors and inhibi- } \\
\text { tors, glutathione ester }\end{array}$ & $\begin{array}{l}\text { Microcirculation, } \\
\text { neutrophil activity, } \\
\text { lipid peroxidation }\end{array}$ & $\begin{array}{l}\downarrow \text { hepatic injury in } \\
\text { normal and fatty livers }\end{array}$ & NO \\
\hline $\begin{array}{l}\text { Teoh } \\
\text { et al. [15] }\end{array}$ & 2002 & Mice & $2-20 I+10 R$ & 90 & $24 \mathrm{~h}$ & Partial & Nil & Transaminases, histology, & $\downarrow$ hepatocellular injury & $\begin{array}{l}\text { NF-kB and } \\
\text { SAPKs }\end{array}$ \\
\hline $\begin{array}{l}\text { Fernandez } \\
\text { et al. [16] }\end{array}$ & 2002 & Rat & $10 \mathrm{I}+10 \mathrm{R}$ & 90 & $16 \mathrm{~h}$ & Total & Xanthine, XOD & Transaminases, ROS & $\downarrow$ liver and lung injury & $\begin{array}{l}\text { Via xanthine/ } \\
\text { XOD blockade }\end{array}$ \\
\hline $\begin{array}{l}\text { Koti } \\
\text { et al. [42] }\end{array}$ & 2002 & Rat & $5 \mathrm{I}+10 \mathrm{R}$ & 45 & 120 & Partial & $L$-arginine, $L$-NAME & $\begin{array}{l}\text { Transaminases, NOx, } \\
\text { hepatic oxygenation }\end{array}$ & $\begin{array}{l}\downarrow \text { hepatocellular injury, } \\
\uparrow \text { intracellular oxygenation }\end{array}$ & NO \\
\hline $\begin{array}{l}\text { Koti } \\
\text { et al. [41] }\end{array}$ & 2002 & Rat & $5 \mathrm{I}+10 \mathrm{R}$ & 45 & 120 & Partial & $L$-arginine, $L$-NAME & $\begin{array}{l}\text { Transaminases, NOx, } \\
\text { cGMP, microcirculation }\end{array}$ & $\begin{array}{l}\downarrow \text { hepatocellular injury, } \\
\uparrow \text { microcirculation }\end{array}$ & NO \\
\hline $\begin{array}{l}\text { Iwasaki } \\
\text { et al. [38] }\end{array}$ & 2002 & Rat & $10 \mathrm{I}+10 \mathrm{R}$ & $\begin{array}{l}15 \times 3 \\
\text { or } 45\end{array}$ & $\begin{array}{l}\text { Up to } \\
180 \mathrm{~min}\end{array}$ & Total & Nil & $\begin{array}{l}\text { Transaminases, TNF, } \\
\text { histology }\end{array}$ & $\begin{array}{l}\uparrow \text { protective effect for inter- } \\
\text { mittent than continuous I }\end{array}$ & Not addressed \\
\hline $\begin{array}{l}\text { Funaki } \\
\text { et al. [62] }\end{array}$ & 2002 & Mice & $15 \mathrm{I}+20 \mathrm{R}$ & 70 & $0-24 \mathrm{~h}$ & Total & Nil & NF- $\kappa \mathrm{B}$ activity & $\downarrow N F-\kappa B$ activation & NF-kB \\
\hline $\begin{array}{l}\text { Ricciardi } \\
\text { et al. [63] }\end{array}$ & 2002 & Pig & $15 \mathrm{I}+15 \mathrm{R}$ & & & $\begin{array}{l}\text { Cold } \\
\text { storage }\end{array}$ & Genistein, chelerythrine & TK, PKC, NF-кB & $\begin{array}{l}\text { TK, PKC, } \\
\text { NF- } \mathrm{KB} \text { activation }\end{array}$ & $\begin{array}{l}\text { PKC and TK, } \\
\text { NF-KB }\end{array}$ \\
\hline
\end{tabular}


Table 1 (continued)

\begin{tabular}{|c|c|c|c|c|c|c|c|c|c|c|}
\hline $\begin{array}{l}\text { Study } \\
\text { group }\end{array}$ & Year & Species & $\begin{array}{l}\text { IPC time } \\
\text { min }\end{array}$ & $\begin{array}{l}\text { Ischemia } \\
\text { time } \\
\text { min }\end{array}$ & $\begin{array}{l}\text { Reper- } \\
\text { fusion } \\
\text { time, } \min \end{array}$ & $\begin{array}{l}\text { Hepatic } \\
\text { ischemia }\end{array}$ & $\begin{array}{l}\text { Pharmacological } \\
\text { manipulations }\end{array}$ & Parameters assessed & Outcome of IPC & $\begin{array}{l}\text { Proposed } \\
\text { mechanism }\end{array}$ \\
\hline $\begin{array}{l}\text { Arai } \\
\text { et al. [48] }\end{array}$ & 1999 & Rat & $5 \mathrm{I}+5 \mathrm{R}$ & $30 \mathrm{~h}^{\mathrm{a}}$ & 15 & $\begin{array}{l}\text { Cold } \\
\text { storage (UW }\end{array}$ & Nil & $\begin{array}{l}\text { SEC killing, Kupffer cell } \\
\text { activation }\end{array}$ & $\begin{array}{l}\downarrow \text { SEC death and } \mathrm{KC} \\
\text { activation }\end{array}$ & Not addressed \\
\hline $\begin{array}{l}\text { Arai } \\
\text { et al. [49] }\end{array}$ & 2000 & Rat & $5 \mathrm{I}+5 \mathrm{R}$ & $30 \mathrm{~h}^{\mathrm{a}}$ & & $\begin{array}{l}\text { Cold } \\
\text { storage } \\
\text { (UW) }\end{array}$ & $\begin{array}{l}\text { AdoR A1, A2 agonists } \\
\text { and antagonists }\end{array}$ & SEC killing, SEC cAMP & $\begin{array}{l}\downarrow \text { SEC death and } \\
\uparrow \text { cAMP }\end{array}$ & $\begin{array}{l}\text { Adenosine A2 } \\
\text { receptors via } \\
\text { cAMP }\end{array}$ \\
\hline $\begin{array}{l}\text { Carini } \\
\text { et al. [54] }\end{array}$ & 2000 & Rat & $10 \mathrm{I}+10 \mathrm{R}$ & 90 & & Hypoxia & $\begin{array}{l}\text { PKC stimulators } \\
\text { and inhibitors }\end{array}$ & $\begin{array}{l}\text { Hepatocyte viability, } \mathrm{pH}, \\
\mathrm{Na}^{+}, \text {ATP }\end{array}$ & $\downarrow$ hepatocyte cell death & PKC \\
\hline $\begin{array}{l}\text { Carini } \\
\text { et al. [55] }\end{array}$ & 2001 & Rat & $10 \mathrm{I}+10 \mathrm{R}$ & 90 & & Hypoxia & $\begin{array}{l}\text { AdoR A1, A2 agonists } \\
\text { and antagonists; PKC, } \\
\text { MEK inhibitors }\end{array}$ & $\begin{array}{l}\text { Cell viability, PKC iso- } \\
\text { enzyme activity, P38 } \\
\text { MAPK activity }\end{array}$ & $\begin{array}{l}\text { hepatocyte killing } \\
\downarrow \text { reduced by } 35 \%\end{array}$ & $\begin{array}{l}\text { Adenosine A2 } \\
\text { receptors, Gi pro- } \\
\text { teins, phospholip- } \\
\text { ase C, PKC, P38 } \\
\text { MAPK }\end{array}$ \\
\hline $\begin{array}{l}\text { Compagnon } \\
\text { et al. [56] }\end{array}$ & 2002 & Rat & $\begin{array}{l}10 \text { anoxia } \\
+10 \text { reoxy- } \\
\text { genation }\end{array}$ & $\begin{array}{l}30+ \\
24 \\
-48 h^{a}\end{array}$ & 60 & $\begin{array}{l}\text { Warm } \\
\text { ischaemia } \\
+ \text { cold } \\
\text { storage }\end{array}$ & Nil & $\begin{array}{l}\text { LDH, ATP, oxygen uptake, } \\
\text { protein synthesis }\end{array}$ & $\begin{array}{l}\uparrow \text { hepatocyte viability, } \\
\uparrow \text { ATP and protein } \\
\text { synthesis }\end{array}$ & Not addressed \\
\hline $\begin{array}{l}\mathrm{I}=\mathrm{Isch} \\
\mathrm{GPT}=\mathrm{g} \\
\mathrm{MPO}=\mathrm{r} \\
\mathrm{ICG}=\text { in } \\
\mathrm{XOD}=\mathrm{x} \\
\mathrm{cAMP}= \\
\text { a Cold isch }\end{array}$ & $\begin{array}{l}\text { mia; } R \\
\text { lutama } \\
\text { myelop } \\
\text { ndocyar } \\
\text { xanthin } \\
\text { cyclic } \\
\text { hemia. }\end{array}$ & $\begin{array}{l}=\text { reperfu } \\
\text { e pyruvic } \\
\text { roxidase; } \\
\text { ine green } \\
\text { oxidase; } \\
\text { denosine }\end{array}$ & $\begin{array}{l}\text { sion; LFTs }=1 \\
\text { transaminas } \\
\text { IL-6 = interl } \\
\text { OLT = ortho } \\
5^{\prime}-\mathrm{NT}=5^{\prime}-\mathrm{n} \\
\text { monophosph }\end{array}$ & $\begin{array}{l}\text { liver funct } \\
\text { e; ATP = a } \\
\text { eukin-6; A } \\
\text { topic live } \\
\text { ucleotidas } \\
\text { late; SAPK }\end{array}$ & $\begin{array}{l}\text { on tests; } \mathrm{N} \\
\text { denosine tr } \\
\text { MPK = ade } \\
\text { transplant } \\
\text {; MIP-2 = } \\
\text { S = stress-a }\end{array}$ & $\begin{array}{l}=\text { nitric oxid } \\
\text { losphate; LD } \\
\text { sine monoph } \\
\text { on; IEGs = in } \\
\text { crophage inf } \\
\text { vated protein }\end{array}$ & $\begin{array}{l}\text { He synthase; cNOS = cons } \\
\mathrm{H}=\text { lactate dehydrogena } \\
\text { osphate-activated protei } \\
\text { mmediate early genes; LF } \\
\text { lammatory protein-2; M } \\
\text { kinases; p38 MAPK = p }\end{array}$ & $\begin{array}{l}\text { titutive nitric oxide synthase; } \\
\text { se; } \mathrm{HM}=\text { hepatic microcircul } \\
\mathrm{n} \text { kinase; ICAM = intercellula } \\
\mathrm{O}=\text { lipid peroxidase; } \mathrm{SOD}= \\
\mathrm{DA}=\text { malondialdehyde; } \mathrm{ROS} \\
38 \text { mitogen-activated protein }\end{array}$ & $\begin{array}{l}\text { ation; } \\
\text { sudhesion molecule; } \\
\text { superoxide dismutase; } \\
=\text { reactive oxygen specie } \\
\text { kinase; } \uparrow=\text { increased; } \downarrow\end{array}$ & creased. \\
\hline
\end{tabular}

decreased hepatocellular injury [17, 18], increased tissue ATP $[12,22]$, decreased tumor necrosis factor- $\alpha$ (TNF- $\alpha)$ $[19,31]$ and IL-6 [31] release, decreased leukocyte/endothelial cell interactions [25], decreased endothelial cell injury [39], increased peripheral liver blood flow [24], increased microcirculation [40, 41], decreased hepatocellular apoptosis [27], preserved energy metabolism [21], increased hepatic intracellular oxygenation [42] and remote organ protection [23]. These studies provide considerable evidence that preconditioning ameliorates ischemia-reperfusion-induced liver injury in the rodent liver. Encouragingly, recent investigations by Clavien et al. [43] have shown that IPC exists in the human liver. In this study, patients undergoing hemihepatectomies under inflow occlusion showed inhibition of sinusoidal endothelial cell (SEC) apoptosis within $30 \mathrm{~min}$ of reperfusion in the preconditioned livers. In a murine model of partial hepatic ischemia, the same group showed that IPC also inhibits apoptosis of hepatocytes at later stages of reperfusion [27].

The steatotic liver is particularly susceptible to ischemia-reperfusion injury resulting in poor outcome following liver surgery [44] and transplantation [45, 46]. There is, therefore, an urgent need for strategies against ischemia-reperfusion injury to increase the number of organs available for liver transplantation and, moreover, improve the outcomes after transplantation of fatty livers and after hepatic resections. The recent report by Serafin et al. [47] shows IPC increases the tolerance of fatty livers to ischemia-reperfusion injury in rats. In this study obese Zucker rats subjected to $60 \mathrm{~min}$ of lobar liver ischemia had $70 \%$ survivors at 30 days in the ischemically preconditioned group as compared to no survivors in the ischemic controls.

\section{Studies on Cold Ischemia}

The protective effect of IPC is not restricted to warm ischemia and decreased tissue damage in cold preserved livers (cold storage-reperfusion injury) after IPC has been demonstrated in small and large animal models. In rat livers, IPC prior to storage in cold University of Wisconsin (UW) solution for $30 \mathrm{~h}$ decreased SEC death and Kupffer cell (KC) activation $[48,49]$. In another study combining two sets of experiments, IPC prior to preservation of rat livers in cold UW solution for $30 \mathrm{~h}$ decreased SEC detachment and activities of matrix metalloproteinases, and also decreased SEC apoptosis after $1 \mathrm{~h}$ of reperfusion in an isolated perfused rat liver model [50]. In a rat liver transplant model IPC protected liver grafts from ischemiareperfusion injury [26]. Furthermore, in a recent study in 
cold-preserved rat livers Arai et al. [51] have observed that the benefit of IPC extends not only to the ipsilateral lobe, but also to the contralateral lobe resulting in an improved graft survival after orthotopic liver transplantation. In this study the authors observe that 'such heterologous preconditioning provides a new means to protect liver tissue against ischemia reperfusion injury without imposing ischemia on the target tissue' [51]. IPC also increased resistance to cold ischemic liver injury in pigs $[52,53]$.

\section{Studies on Isolated Hepatocytes}

The hepatoprotective response of IPC has also been shown in isolated hepatocytes. In in vitro studies on freshly isolated hepatocytes, preconditioned hepatocytes showed increased resistance to cell killing during hypoxic incubation [54, 55]. Another study has shown IPCimproved hepatocyte viability and energy metabolism in a model of isolated rat hepatocytes subjected to hypothermic preservation injury preceded by normothermic ischemia [56].

The above studies mostly in rodent livers have shown liver protection by IPC to warm and cold ischemia. However, there are a few published studies which have suggested that hepatic IPC may have only limited benefit. A study by Adam et al. [57] in fact suggested that preconditioning had a deleterious effect on hepatic tolerance to cold ischemia. This study used a model of isolated perfused livers from Wistar rats [57]. Preconditioning protocol of 5 or $10 \mathrm{~min}$ ischemia followed by $10 \mathrm{~min}$ reperfusion before liver harvesting, prior to extended cold ischemia of $24 \mathrm{~h}$ resulted in extensive reperfusion injury, increased vascular resistance and increased transaminases and LDH release. In a larger animal model using pigs, a preconditioning protocol of repeated $10 \mathrm{~min}$ ischemia followed by $10 \mathrm{~min}$ reperfusion, prior to $120 \mathrm{~min}$ or 200 min sustained ischemia was tested [58]. In the 120min ischemia group IPC increased bile flow and ATP, but the degree of necrosis and apoptosis was not different from the control group. With $200 \mathrm{~min}$ ischemia IPC resulted in no significant differences in bile flow, ATP and liver enzymes from control group, and the degree of necrosis and apoptosis was in fact greater in preconditioned livers. This study suggested that IPC conferred some functional protection against reversible ischemia but no protection from prolonged ischemia in pigs [58]. The major difference between this study and those showing benefits with IPC is the use of three cycles of preconditioning in comparison with a single episode. In a more recent study Rudiger et al. [36] noted that in mice IPC resulted in $100 \%$ animal survival with no morphological parenchymal injury after 75 min sustained ischemia as against $14 \%$ survival with significant parenchymal injury after $120 \mathrm{~min}$ ischemia.

Thus, a large body of evidence favors liver protection by IPC from injury in both warm and cold ischemia. The existence of IPC in the liver has been demonstrated in rodents, pig and humans. Although most of the data on hepatic IPC has been gathered in rodents and it is recognized that information on preconditioning in rats may not always be extrapolated to larger species and humans, the recent report by Clavien et al. [43] of the first human study is a thoughtful example of potential clinical application of the preconditioning effect.

\section{Possible Mechanisms of Preconditioning}

The precise mechanism of the IPC response is unknown. From studies on preconditioned myocardium, it is widely accepted that IPC is mediated via a receptortargeting mechanism $[59,60]$. Molecules released during ischemia attach to cellular receptors and contribute to preconditioning response. The candidate compounds implicated in liver IPC include adenosine [17, 20, 25, 48, 49], protein kinase $\mathrm{C}$ (PKC) [53-55], nitric oxide (NO) $[13,17,20,26,41,42]$, heat shock proteins (HSPs) [29, 61], tyrosine kinases [52], mitogen-activated protein kinases [55], oxidative stress [35, 50], nuclear factor $\kappa \mathrm{B}$ $(\mathrm{NF}-\mathrm{\kappa B})[62,63]$, and modulation of apoptosis cascade $[14,27]$. However the characterizations of these candidate compounds into different processes in the preconditioning cascade such as initiating trigger, signalling pathway and end effector are not defined and the interrelationship between these processes is unknown. In the liver, the most investigated molecules are NO [13], adenosine [49], PKC [54] and HSPs [29]. This article reviews the major developments in the characterization of these proposed mechanisms of preconditioning (fig. 2). Other mechanisms will not be discussed in further detail.

\section{The Role of Adenosine}

Adenosine is an extracellular molecule proposed both as 'trigger' and 'mediator' of IPC [3]. During ischemia, adenosine triphosphate is degraded to adenosine. The extracellular adenosine released in large quantities during ischemia is believed to play a role in the protective effect of IPC during reperfusion of ischemic tissue. Ischemiareperfusion injury is associated with neutrophil and leukocyte activation and primary microvascular failure. 


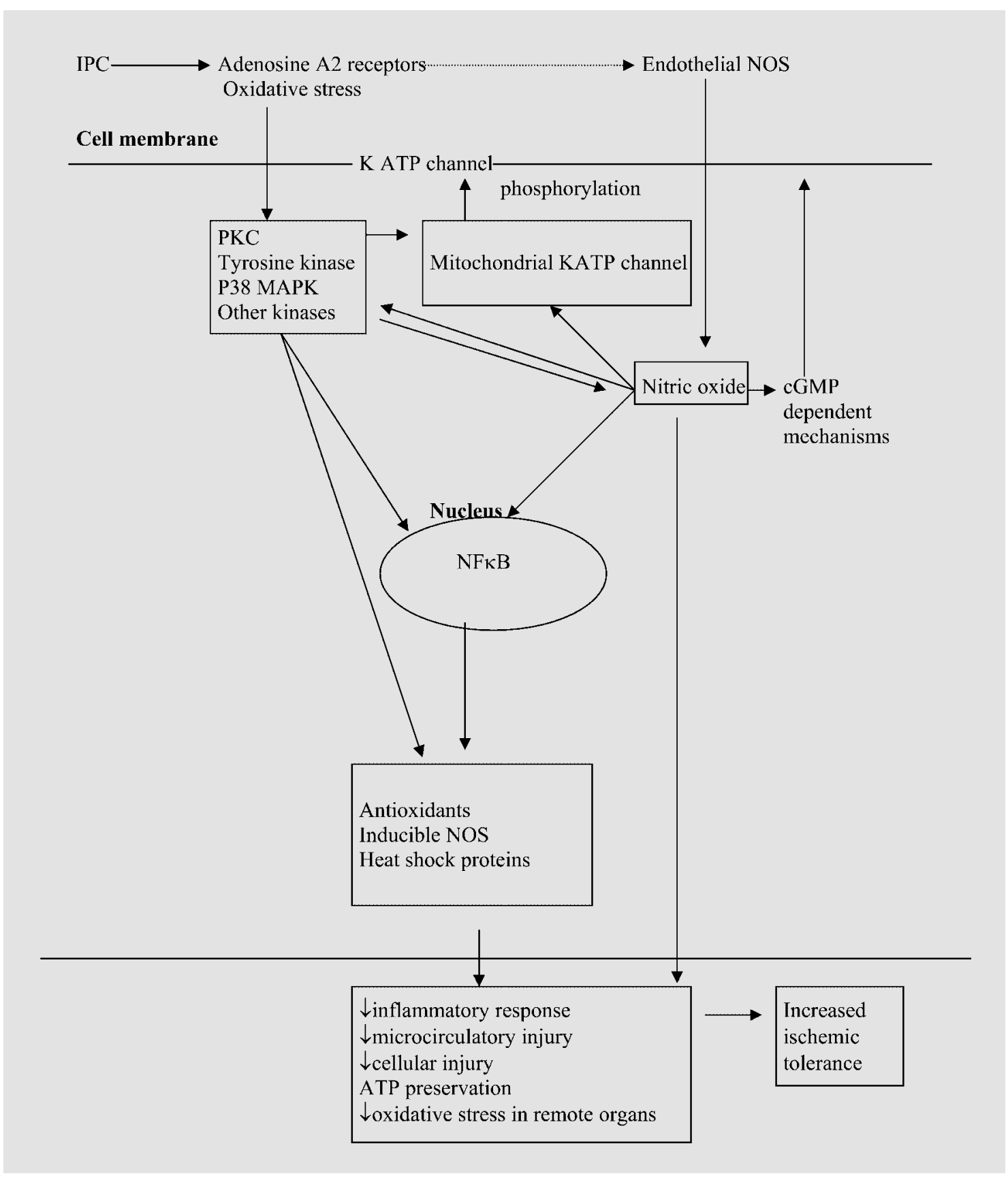

Fig. 2. Schematic illustration of possible mechanisms involved in IPC. NOS = Nitric oxide synthase; KATP = potassium-dependent ATP channel; cGMP = cyclic guanosine monophosphate; MAPK = mitogen-activated protein kinase.

Adenosine inhibits leukocyte adhesion, decreases expression of adhesion molecules and inhibits neutrophil and platelet function [64, 65]. Adenosine also inhibits free radical production $[66,67]$, which are important mediators of cellular damage in the early phase of ischemiareperfusion injury, and is a potent vasodilator [68]. The above would suggest adenosine may be protective against ischemia-reperfusion injury and the effects of adenosine in IPC are likely to be multifactorial. Most of the data on the role of adenosine in IPC has been gathered in cardiac muscle [69-71] and extrapolated to skeletal muscle [5] and kidneys [8]. 
Over the recent years a few studies have gathered evidence of the involvement of adenosine in liver IPC. Whereas A1 receptors have been implicated in the myocardium [72], A2 receptors have been proposed to be the adenosine receptor subtype likely to be expressed in the liver [49]. The existence of adenosine A2 receptors on hepatic SEC is supported indirectly by demonstrating a dose-dependent increase in cAMP by adenosine and selective A2 receptor agonist CGS-21680 [49]. In this study by Arai et al. [49], adenosine A2 receptor blockade prevented the protective effect of IPC in rat livers preserved in cold UW solution. IPC and administration of adenosine A2 receptor agonist, in this study, decreased SEC death and increased cAMP level [49]. The authors have proposed that SEC protection by IPC is mediated by activation of adenosine $\mathrm{A} 2$ receptors producing an increase in cAMP levels in SEC, but the mechanism downstream to increased cAMP, by which adenosine decreases SEC injury, is not explained. The same authors have previously shown that IPC suppressed KC activation and have stipulated the involvement of adenosine $\mathrm{A} 2$ receptors in this response [48]. IPC-induced protection of SECs can have profound implications for preservation of livers for transplantation, since SECs are more susceptible to cold preservation injury $[73,74]$ in contrast to hepatocytes which are vulnerable to warm ischemia-reperfusion injury [75]. SEC injury rather than hepatocellular injury has been shown to be responsible for graft failure from cold ischemia-reperfusion injury [73, 74, 76]. Peralta et al. [17] have postulated activation of adenosine $\mathrm{A} 2$ receptors with subsequent formation of $\mathrm{NO}$ to play a role in mediating IPC against warm ischemia-reperfusion injury. In this study adenosine administration in the presence of a NO donor reproduced the protective effect of IPC on hepatic parenchymal cells. In another study, a 3-fold increase in adenosine after IPC was associated with decreased parenchymal tissue damage [20]. Both IPC and increasing endogenous adenosine concentrations with the adenosine uptake inhibitor dipyridamole decreased hepatic leukocyte/endothelial cell interactions after ischemia-reperfusion injury [25]. All of the above studies have been carried out in rats and although the evidence is limited, suggest that adenosine modulates IPC-induced protection of nonparenchymal and parenchymal cells against cold and warm hepatic ischemia-reperfusion injury in the rat liver. There are no studies challenging the involvement of adenosine in the rat liver.

The data on adenosine from IPC studies in rat livers contradicts the information gathered in the rat heart. The role of adenosine in myocardial preconditioning is sup- ported indirectly by studies in rabbits [77], pigs [78], dogs [79], and humans [80] demonstrating abolition of preconditioning by adenosine receptor blockade. However in rats, it is evident that adenosine has no role in IPC of the myocardium [81]. IPC is effective in the absence of extracellular accumulation of adenosine in the rat heart [82]. Thus, adenosine does not appear to be an endogenous trigger or obligatory mediator of preconditioning in rat hearts. Thus, in the rat species the adenosine concept does not seem to apply consistently to different tissues. It therefore seems likely that adenosine may only be a mediator to IPC of the liver but not a sole mechanism.

\section{The Role of PKC}

The PKC-mediated signalling pathway of myocardial preconditioning was proposed by Downey and colleagues $[60,83]$. The hypothesis proposes that during preconditioning ischemia $\mathrm{G}$ protein activation following $\mathrm{G}$ protein coupling with adenosine receptors leads to PKC activation and subsequent translocation from the cytosol to the membrane where it phosphorylates substrate proteins to induce tolerance to subsequent ischemia [60]. However conflicting results in some species, particularly large animals where the concept does not apply consistently, would suggest that PKC activation is an epiphenomenon or secondary effect and not a primary mediator of the cardioprotective effects of preconditioning [84, 85]. Most of the evidence surrounding the PKC hypothesis is indirect and based on a pharmacological approach using PKC activators and inhibitors. Many of the inhibitors are not specific to PKC and are also isoform nonspecific. The above reviewers [84, 85] highlighted the limitations of pharmacological methods and also the fact that studies using isoform specific antibodies may not indicate activity of these specific PKC isoforms. Further, information on events downstream of PKC activation and the end effector of preconditioning is lacking at present.

In recent years, few studies have evaluated the evidence for involvement of PKC in preconditioning of the liver. This evidence is indirect and based on a pharmacological approach. Carini et al. [54] used an in vitro model of isolated rat hepatocytes and proposed that hypoxic preconditioning was mediated via PKC-mediated activation of vacuolar proton ATPase. In this study the increased tolerance of preconditioned hepatocytes to hypoxia was abolished by inhibition of PKC with chelerythrine or blocking vacuolar proton ATPase with bafilomycin A1 and mimicked by stimulators of PKC, 4 $\beta$-phorbol-12myristate-13-acetate (PMA) and 1,2-dioctanoyl-glycerol (1,2-DOG). The authors observed that the prevention of 
intracellular acidosis and of cytosolic $\mathrm{Na}^{+}$increase during hypoxia was associated with decreased hypoxic injury in preconditioned hepatocytes [54]. In another study, the same authors observed that preconditioning was abolished by adenosine A2a receptor antagonist and have proposed a signalling pathway involving adenosine A2a receptors, PKC and kinases downstream of PKC (p38 mitogen-activated protein kinase) to be involved in hypoxic preconditioning of isolated rat hepatocytes [55]. However downstream of this point, the mechanisms by which liver injury is decreased have not been explained. In the heart, it has been suggested that the kinase cascade activated during preconditioning leads to the opening of mitochondrial $\mathrm{K}_{\mathrm{ATP}}$ channels [86] but there is no evidence that these are the end effectors. There is data to suggest that mitochondrial $\mathrm{K}_{\mathrm{ATP}}$ channels may simply act as another signal transduction step [87]. The kinase cascade can also stimulate phosphorylation of HSPs [88], activation of the transcription factor NF- $\mathrm{KB}$ [89] and upregulation of inducible NO synthase [90] but the link with end effects of preconditioning has not been established. Ricciardi et al. $[52,53]$ have extended support for involvement of PKC and tyrosine kinase in liver IPC in larger animals. In one study, tolerance of ischemically preconditioned pig livers to cold ischemia was abolished by pretreatment with the PKC inhibitor chelerythrine [53]. In another study by the same authors pretreatment with tyrosine the kinase inhibitor genistein abolished the preconditioning effect in coldpreserved pig livers [52]. While these data support a role for PKC in IPC, they still do not prove that PKC is responsible for preconditioning.

\section{The Role of HSP}

HSPs are intracellular stress proteins that have been shown to accumulate after hyperthermia and ischemia [91]. The concept of sublethal whole animal hyperthermia conferring tolerance to other stresses such as ischemia and lethal endotoxin exposure is referred to as hyperthermic preconditioning and has been associated with HSP accumulation $[92,93]$. In the rat liver, tolerance to ischemic injury has been associated with production of various inducible HSPs: HSP72 [30, 94], HSP73 [30] and HSP70 and HO-1/HSP32 [95, 96]. Ishikawa et al. [61] have proposed that in heat shock-preconditioned rat livers HSPs maintain mitochondrial membrane integrity during the ischemic episode, to produce energy-rich phosphates during reperfusion and thus contribute to ischemic tolerance. In an in vivo study in rats by Kume et al. [29] the reduced postischemic hepatocellular injury and improved survival was associated with overexpression of HSP72 in ischemi- cally preconditioned livers as well as in the livers preconditioned with heat shock. In this study HSP72 was detected within 6-72 $\mathrm{h}$ after heat exposure and the authors have proposed that HSP72 production is associated with a delayed protective effect of IPC. The link between HSP72 and delayed effect of IPC has not been explained. It is also not clear whether HSP production and accumulation is the reason for resistance to ischemia or merely a marker of tolerance [97].

While these studies demonstrate that HSPs are detected after preconditioning, the molecular mechanism of protection associated with HSP accumulation is not explained and these studies do not prove that HSPs are responsible for preconditioning.

\section{The Role of NO}

NO is a colorless, odorless, free radical gas which has been identified as an important signaling molecule in almost every tissue in the body. NO is produced from $L$ arginine by the enzyme NO synthase. In the liver, as in many other organs NO has many actions and cellular sources. Recent evidence supports the role of NO in regulating perfusion of the hepatic microcirculation [98]. The breakdown of microvascular perfusion with subsequent impairment of tissue oxygenation plays a central role in the pathophysiology of ischemia-reperfusion-induced injury of the liver [99]. Treatment of rats with nonspecific NO synthase inhibitors resulted in a failure of microvascular perfusion and development of patchy necrosis [100, 101]. Augmentation of NO synthesis with NO donors has been shown to attenuate hepatic ischemia-reperfusion injury and improve posttransplant survival [102]. NO may modulate microvascular perfusion through its vasodilatory effect [103] and through its anti-inflammatory actions including inhibitory effects on stellate cell activation [104], neutrophil adhesion [105] and platelet aggregation [101].

It has been proposed that NO plays a key role in both initiating and mediating IPC. While functional evidence in the heart indicates that NO modulates both acute and delayed preconditioning, downstream of this point in the biochemical pathway hypotheses are less well established [106, 107]. A recent study by Lochner et al. [108] has proposed that NO through generation of cGMP acts as a trigger of acute preconditioning in rat hearts. Parratt [109] has suggested that endocardial endothelium-derived mediators such as NO may mediate cardioprotective response of IPC by elevation of cGMP, which in turn could reduce energy demand by limiting myocardial cAMP levels by stimulation of cGMP-sensitive cAMP phosphodies- 
terase enzyme. It appears that whereas the acute phase of preconditioning is protein synthesis independent, the late phase requires new protein synthesis. It has been proposed that eNOS-derived NO leads to activation of PKC

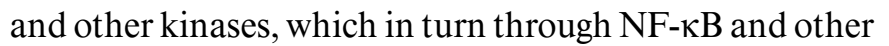
transcription factors leads to an increase in transcription of iNOS [107]. The end effector of IPC in the supposed NO pathway is speculative and cGMP-dependent mechanisms and ATP-sensitive potassium channel have been proposed [107].

In the liver it has been suggested that depending on the rate of its production, $\mathrm{NO}$ may also play a mediating role in preconditioning [110]. NO has been implicated in IPCassociated decreased tissue damage in both warm ischemia [13] and cold ischemic storage [26] of the rat liver. However the link between protective effects of IPC and NO is speculative. Peralta et al. [13] suggested that liver IPC in rats is mediated by the inhibitory action of NO on endothelin. In other studies in rats, the same authors have demonstrated that inhibition of adenosine and simultaneous administration of NO donor offered similar results to IPC [17] and have proposed that activation of adenosine A2 receptors with subsequent NO formation mediates IPC in the rat liver [20]. Yin et al. [26] have postulated that IPC increased resistance to cold ischemic liver injury in rats through stimulation of endogenous NO. In this study pharmacological NO stimulation mimicked and NO inhibition antagonized IPC-associated protection of liver grafts from preservation reperfusion injury in a rat liver transplantation model but the mechanism has not been explained. Recently, our group has shown an increased hepatic intracellular oxygenation [42] and increased hepatic microcirculation [41] with IPC which was associated with increased NO levels. A recent report by Serafin et al. [47] has implicated NO in the preconditioning response for ischemia-reperfusion injury in fatty livers.

NO suppresses apoptosis in endothelial cells. In recent years it has been suggested that apoptosis is the dominant mechanism for cell turnover in the human liver. Apoptosis is a rapid process terminating in nuclear pyknosis and cell death. Recent evidence has shown that apoptosis of SEC and hepatocytes are a feature of ischemia-reperfusion injury in warm [111] and cold [112] ischemia of the liver. The signalling pathways leading to nuclear apoptosis in response to extracellular stimuli involve activation of cysteine proteases known as caspases and release of cytochrome c from the mitochondria [113]. Subsequent activation of downstream caspases such as caspase 3 ultimately executes nuclear apoptosis [114]. Antiapoptotic molecules such as Bcl-2 and caspase inhibitors have been shown to prevent release of mitochondrial cytochrome c [115]. In an experimental model of partial hepatic ischemia, IPC inhibited apoptosis of SEC and hepatocytes and was associated with inhibition of caspase 3 activity [27]. In the study IPC was not associated with higher Bcl-2 or Bcl-xl expression. The link between IPC and inhibition of caspase activity is speculative. NO has been shown to inhibit caspase activity in vitro [116]. Apoptosis in hepatocytes exposed to TNF- $\alpha$ and actinomycin D was prevented by NO. In this study NO produced by an NO donor or through iNOS gene expression inhibited caspase family proteases by S-nitrosylation and prevented cytochrome c release [113]. Other mechanisms for an antiapoptotic effect of NO are increase in cGMP [116] and upregulation of Bcl-2 [117] and HSPs [118]. Thus, potentially liver IPC may be mediated through NO modulation of apoptosis cascade.

\section{Role of IPC in Hepatic Surgery}

Ischemia-reperfusion injury is a major cause of morbidity and mortality following liver surgery and transplantation. In the setting of liver resections, the effects of intermittent inflow occlusion, continuous inflow occlusion and total vascular exclusion during liver resections have been studied in clinical trials [119-121]. Whereas total vascular exclusion was effective in reducing blood loss, it led to unpredictable hemodynamic intolerance, increased morbidity and longer hospital stay [119]. This is not surprising since the state of total vascular exclusion is akin to the anhepatic phase of liver transplantation and hemodynamic consequences on reperfusion would be anticipated. In a prospective evaluation of intermittent inflow occlusion versus no inflow occlusion in patients undergoing liver resections, the former resulted in less blood loss and better preservation of liver function in the early postoperative period [120]. When intermittent versus continuous inflow occlusion were studied in patients undergoing liver resections [121], the group subjected to intermittent inflow occlusion was associated with decreased hepatocellular injury indicated by lower postoperative liver enzymes and serum bilirubin levels. However the intraoperative blood loss during liver transection was significantly higher in this group and this is most likely related to bleeding from the transected surface during successive reperfusion episodes [121]. Thus, the increased blood loss and likely increased duration of surgery due to successive reperfusion episodes may outweigh the benefit of intermittent occlusion on parenchymal tolerance to 
ischemia. Although some liver resections can be performed without vascular inflow occlusion, prolonged ischemia may be unavoidable to achieve radical tumor resection. An ideal protective strategy for human liver surgery would allow a bloodless parenchymal transection and an increased parenchymal tolerance to ischemia. In theory, IPC may obviate the need for intermittent releases of hepatic vascular occlusions and extend safe periods of ischemia by increasing hepatic tolerance to ischemia during hepatic surgery. The potential for clinical application of IPC for hemihepatectomies under inflow occlusion has been demonstrated by Clavien et al. [43]. In this study IPC protected against 30 min of inflow occlusion with patients showing a 2-fold decrease in serum transaminases compared to patients subjected to continuous ischemia only, but no significant differences in duration of surgery, need for intensive care or mortality. This study provides evidence that IPC occurs in the human liver.

In the setting of liver transplantation, ischemia time of the donor liver is a major determinant of graft outcome and patient survival after liver transplantation [122]. Liver transplantation requires mandatory organ ischemia. Warm ischemia to the graft may occur at organ harvest in an unstable donor and cold ischemia occurs during preservation of the liver for transplantation. During implantation of the graft in the recipient, the liver is subjected to further warm ischemia until the vascular anastomoses are completed. Finally reperfusion injury is inevitable following revascularization. Prolonged ischemia results in primary nonfunction or dysfunction of the transplanted liver graft and is associated with biliary and vascular complications $[122,123]$ often resulting in retransplantation. This adversely affects patient outcome and survival. Therefore
IPC is an attractive strategy to assist liver preservation and protect the liver from ischemia-reperfusion injury during transplantation by increasing ischemic tissue tolerance of the liver. As yet there are no reported studies demonstrating clinical benefits of IPC in patients undergoing liver transplantation. Most animal studies have shown that IPC offers a degree of protection against cold ischemia in experimental liver transplantation. This data in animal models is encouraging and clinical studies are required to clarify the potential application of IPC in human liver transplantation.

\section{Conclusions}

The past decade has provided interesting new data establishing the existence of IPC in the liver. IPC is a powerful endogenous means to protect the liver from ischemia. To date one study has demonstrated human clinical benefits of liver IPC. Further clinical studies are required to prove unequivocally that IPC is possible in the human liver. However the central mechanism of IPC remains undefined. Current research has demonstrated that IPC is an endogenous adaptive phenomenon that can be reproduced easily in different models of warm and cold ischemia, and in animals as well as humans. However the causal relationship between the initiating event, biochemical pathways and end effector molecules remains mechanistically undefined and controversial. As the field advances with mechanistically descriptive studies, these controversies in interrelationships in the preconditioning cascade are likely to be resolved and will lead to pharmacological strategies for protecting the liver from ischemic injury.

\section{References}

1 Bilzer M, Gerbes AL: Preservation injury of the liver: Mechanisms and novel therapeutic strategies. J Hepatol 2000;32:508-515.

2 Murry CE, Jennings RB, Reimer KA: Preconditioning with ischemia: A delay of lethal cell injury in ischemic myocardium. Circulation 1986;74:1124-1136.

3 Downey JM, Liu GS, Thornton JD: Adenosine and the anti-infarct effects of preconditioning. Cardiovasc Res 1993;27:3-8.

4 Yellon DM, Alkhulaifi AM, Pugsley WB: Preconditioning of the human myocardium. Lancet 1993;343:276-277.

5 Pang CY, Yang RZ, Zhong A, Xu N, Boyd B, Forrest CR: Acute ischaemic preconditioning protects against skeletal muscle infarction in the pig. Cardiovasc Res 1995;29:782-788.
6 Heurteaux C, Lauritzen I, Widmann C, Lazdunski M: Essential role of adenosine, adenosine A1 receptors, and ATP-sensitive $\mathrm{K}^{+}$channels in cerebral ischemic preconditioning. Proc Natl Acad Sci USA 1995;92:4666-4670.

7 Matsuyama K, Chiba Y, Ihaya A, Kimura T, Tanigawa N, Muraoka R: Effect of spinal cord preconditioning on paraplegia during crossclamping of the thoracic aorta. Ann Thorac Surg 1997;63:1315-1320.

8 Turman MA, Bates CM: Susceptibility of human proximal tubular cells to hypoxia: Effect of hypoxic preconditioning and comparison to glomerular cells. Ren Fail 1997;19:47-60.
9 Hotter G, Closa D, Prados M, et al: Intestinal preconditioning is mediated by a transient increase in nitric oxide. Biochem Biophys Res Commun 1996;222:27-32.

10 Lloris-Carsi JM, Cejalvo D, Toledo-Pereyra LH, Calvo MA, Suzuki S: Preconditioning: Effect upon lesion modulation in warm liver ischemia. Transplant Proc 1993;25:3303-3304.

11 Hardy KJ, McClure DN, Subwongcharoen S: Ischaemic preconditioning of the liver: A preliminary study. Aust NZ J Surg 1996;66:707710.

12 Yoshizumi T, Yanaga K, Soejima Y, Maeda T, Uchiyama H, Sugimachi K: Amelioration of liver injury by ischaemic preconditioning. $\mathrm{Br} \mathrm{J}$ Surg 1998;85:1636-1640. 
13 Peralta C, Closa D, Hotter G, Gelpi E, Prats N, Rosello-Catafau J: Liver ischemic preconditioning is mediated by the inhibitory action of nitric oxide on endothelin. Biochem Biophys Res Commun 1996;229:264-270.

14 Peralta C, Perales JC, Bartrons R, et al: The combination of ischemic preconditioning and liver Bcl-2 overexpression is a suitable strategy to prevent liver and lung damage after hepatic ischemia-reperfusion. Am J Pathol 2002;160: 2111-2122

15 Teoh N, Dela Pena A, Farrell G: Hepatic ischemic preconditioning in mice is associated with activation of NF-kappaB, p38 kinase, and cel cycle entry. Hepatology 2002;36:94-102.

16 Fernandez L, Heredia N, Grande L, et al: Preconditioning protects liver and lung damage in rat liver transplantation: Role of xanthine/xanthine oxidase. Hepatology 2002;36:562-572.

17 Peralta C, Hotter G, Closa D, Gelpi E, Bulbena O, Rosello-Catafau J: Protective effect of preconditioning on the injury associated to hepatic ischemia-reperfusion in the rat: Role of nitric oxide and adenosine. Hepatology 1997;25 934-937.

18 Peralta C, Closa D, Xaus C, Gelpi E, RoselloCatafau J, Hotter G: Hepatic preconditioning in rats is defined by a balance of adenosine and xanthine. Hepatology 1998;28:768-773.

19 Peralta C, Prats N, Xaus C, Gelpi E, RoselloCatafau J: Protective effect of liver ischemic preconditioning on liver and lung injury induced by hepatic ischemia-reperfusion in the rat. Hepatology 1999;30:1481-1489.

20 Peralta C, Hotter G, Closa D, et al: The protective role of adenosine in inducing nitric oxide synthesis in rat liver ischemia preconditioning is mediated by activation of adenosine A2 receptors. Hepatology 1999;29:126-132.

21 Peralta C, Bartrons R, Riera L, et al: Hepatic preconditioning preserves energy metabolism during sustained ischemia. Am J Physiol Gastrointest Liver Physiol 2000;279:G163-G171.

22 Peralta C, Bartrons R, Serafin A, et al: Adenosine monophosphate-activated protein kinase mediates the protective effects of ischemic preconditioning on hepatic ischemia-reperfusion injury in the rat. Hepatology 2001;34:11641173.

23 Peralta C, Fernandez L, Panes J, et al: Preconditioning protects against systemic disorders associated with hepatic ischemia-reperfusion through blockade of tumor necrosis factorinduced P-selectin up-regulation in the rat. Hepatology 2001;33:100-113.

24 Nilsson B, Friman S, Gustafsson BI, Delbro DS: Preconditioning protects against ischemia/ reperfusion injury of the liver. J Gastrointest Surg 2000;4:44-49.

25 Howell JG, Zibari GB, Brown MF, et al: Both ischemic and pharmacological preconditioning decrease hepatic leukocyte/endothelial cell interactions. Transplantation 2000;69:300-303.

26 Yin DP, Sankary HN, Chong AS, et al: Protective effect of ischemic preconditioning on liver preservation-reperfusion injury in rats. Transplantation 1998;66:152-157.
27 Yadav SS, Sindram D, Perry DK, Clavien PA: Ischemic preconditioning protects the mouse liver by inhibition of apoptosis through a caspase-dependent pathway. Hepatology 1999;30: 1223-1231.

28 Nakayama H, Yamamoto Y, Kume M, et al: Pharmacologic stimulation of adenosine A2 receptor supplants ischemic preconditioning in providing ischemic tolerance in rat livers. Surgery 1999;126:945-954.

29 Kume M, Yamamoto Y, Saad S, et al: Ischemic preconditioning of the liver in rats: Implications of heat shock protein induction to increase tolerance of ischemia-reperfusion injury. J Lab Clin Med 1996;128:251-258.

30 Kume M, Yamamoto Y, Yamagami K, Ishikawa Y, Uchinami H, Yamaoka Y: Pharmacological hepatic preconditioning: Involvement of 70-kDa heat shock proteins (HSP72 and HSP73) in ischaemic tolerance after intravenous administration of doxorubicin. Br J Surg 2000;87:1168-1175.

31 Tsuyama H, Shimizu K, Yoshimoto K, et al: Protective effect of ischemic preconditioning on hepatic ischemia-reperfusion injury in mice. Transplant Proc 2000;32:2310-2313.

32 Yamada F, Abe T, Saito T, Tsuciya T, Ishii S, Gotoh M: Ischemic preconditioning enhances regenerative capacity of hepatocytes after prolonged ischemia. Transplant Proc 2001;33: 956.

33 Saito T, Ishii S, Abe T, et al: Effect of preconditioning in the liver against ischemia/reperfusion injury, protection of sinusoidal cells and alterations of gene transcription. Transplant Proc 2001;33:849.

34 Zhang Y, Zhang B, Pan R: Protective effect of ischemic preconditioning on liver. Chin $\mathrm{J}$ Traumatol 2001:4:123-125.

35 Peralta C, Bulbena O, Xaus C, et al: Ischemic preconditioning: A defense mechanism against the reactive oxygen species generated after hepatic ischemia reperfusion. Transplantation 2002;73:1203-1211.

36 Rudiger HA, Kang K-J, Sindram D, Riehle H$\mathrm{M}$, Clavien PA: Comparison of ischemic preconditioning and intermittent and continuous inflow occlusion in the murine liver. Ann Surg 2002;235:400-407.

37 Ajamieh H, Merino N, Candelario-Jalil E, et al: Similar protective effect of ischaemic and ozone oxidative preconditionings in liver ischaemia/reperfusion injury. Pharmacol Res 2002;45:333-339.

38 Iwasaki Y, Tagaya N, Hattori Y, Yamaguchi K, Kubota K: Protective effect of ischemic preconditioning against intermittent warm-ischemia-induced liver injury. J Surg Res 2002; 107:82-92.

39 Ishii S, Abe T, Saito T, et al: Effects of preconditioning on ischemia/reperfusion injury of hepatocytes determined by immediate early gene transcription. J Hepatobiliary Pancreat Surg 2001;8:461-468.

40 Zapletal C, Maksan SM, Lehmann T, et al: Ischemic preconditioning improves liver microcirculation after ischemia/reperfusion. Transplant Proc 1999;31:3260-3262.
41 Koti RS, Yang W, Dashwood MR, Davidson BR, Seifalian AM: Effect of ischemic preconditioning on hepatic microcirculation and function in a rat model of ischemia reperfusion injury. Liver Transpl 2002;8:1182-1191.

42 Koti RS, Yang W, McBride AG, Seifalian AM, Davidson BR: The relationship of hepatic tissue oxygenation with nitric oxide metabolism in ischemic preconditioning of the liver. FASEB J 2002; 16:1654-1656.

43 Clavien PA, Yadav S, Sindram D, Bentley RC: Protective effects of ischemic preconditioning for liver resection performed under inflow occlusion in humans. Ann Surg 2000;232:155162.

44 Makuuchi M, Mori T, Gunven P, et al: Safety of hemihepatic vascular occlusion during resection of the liver. Surg Gynecol Obstet 1989; 130:824-831.

45 Todo S, Demetris AJ, Makowka L, et al: Primary nonfunction of hepatic allografts with preexisting fatty infiltration. Transplantation 1989; 47:903.

46 Adam R, Reynes M, Johann M, et al: The outcome of steatotic grafts in liver transplantation. Transplant Proc 1991;23:1538-1540.

47 Serafin A, Rosello-Catafau J, Prats N, Xaus C, Gelpi E, Peralta C: Ischemic preconditioning increases the tolerance of fatty liver to hepatic ischemia-reperfusion injury in the rat. Am J Pathol 2002;161:587-601.

48 Arai M, Thurman RG, Lemasters JJ: Involvement of Kupffer cells and sinusoidal endothelial cells in ischemic preconditioning to rat livers stored for transplantation. Transplant Proc 1999;31:425-427.

49 Arai M, Thurman RG, Lemasters JJ: Contribution of adenosine $\mathrm{A}(2)$ receptors and cyclic adenosine monophosphate to protective ischemic preconditioning of sinusoidal endothelial cells against storage/reperfusion injury in rat livers. Hepatology 2000;32:297-302.

50 Sindram D, Rudiger HA, Upadhya AG, Strasberg SM, Clavien PA: Ischemic preconditioning protects against cold ischemic injury through an oxidative stress dependent mechanism. J Hepatol 2002;36:78-84.

51 Arai M, Thurman RG, Lemasters JJ: Ischemic preconditioning of rat livers against cold storage-reperfusion injury: Role of nonparenchymal cells and the phenomenon of heterologous preconditioning. Liver Transpl 2001;7:292299.

52 Ricciardi R, Schaffer BK, Kim RD, et al: Protective effects of ischemic preconditioning on the cold-preserved liver are tyrosine kinase dependent. Transplantation 2001;72:406-412.

53 Ricciardi R, Meyers WC, Schaffer BK, et al Protein kinase $\mathrm{C}$ inhibition abrogates hepatic ischemic preconditioning responses. J Surg Res 2001;97:144-149.

54 Carini R, De Cesaris MG, Splendore R, Bagnati M, Albano E: Ischemic preconditioning reduces $\mathrm{Na}(+)$ accumulation and cell killing in isolated rat hepatocytes exposed to hypoxia. Hepatology 2000;31:166-172. 
55 Carini R, Cesaris MG, Splendore R, et al: Signal pathway involved in the development of hypoxic preconditioning in rat hepatocytes. Hepatology 2001;33:131-139.

56 Compagnon P, Wang H, Southard J, Mangino $\mathrm{M}$ : Ischemic preconditioning in a rodent hepatocyte model of liver hypothermic preservation injury. Cryobiology 2002;44:269-278.

57 Adam R, Arnault I, Bao YM, Salvucci M, Sebagh M, Bismuth H: Effect of ischemic preconditioning on hepatic tolerance to cold ischemia in the rat. Transpl Int 1998;11(suppl 1):S168-S170.

58 Schulz R, Walz MK, Behrends M, Neumann T, Gerken G, Heusch G: Minimal protection of the liver by ischemic preconditioning in pigs. Am J Physiol Heart Circ Physiol 2001;280: H198-H207.

59 Dekker LR: Toward the heart of ischemic preconditioning. Cardiovasc Res 1998;37:14-20.

60 Nakano A, Cohen MV, Downey JM: Ischemic preconditioning. From basic mechanisms to clinical applications. Pharmacol Ther 2000;86: 263-275.

61 Ishikawa Y, Yamamoto Y, Kume M, et al: Heat shock preconditioning on mitochondria during warm ischemia in rat livers. J Surg Res 1999;87:178-184

62 Funaki H, Shimizu K, Harada S, et al: Essential role for nuclear factor kappaB in ischemic preconditioning for ischemia-reperfusion injury of the mouse liver. Transplantation 2002;74:551556.

63 Ricciardi R, Shah SA, Wheeler SM, et al: Regulation of NFkappaB in hepatic ischemic preconditioning. J Am Coll Surg 2002;195:319_ 326.

64 Bouma MG, van den Wildenberg FA, Buurman WA: The anti-inflammatory potential of adenosine in ischemia-reperfusion injury: Established and putative beneficial actions of a retaliatory metabolite. Shock 1997;8:313-320.

65 Keller MW, Geddes L, Spotnitz W, Kaul S Duling BR: Microcirculatory dysfunction following perfusion with hyperkalemic, hypothermic, cardioplegic solutions and blood reperfusion. Effects of adenosine. Circulation 1991;84: 2485-2494.

66 Nolte D, Lehr HA, Messmer K: Adenosine inhibits postischemic leukocyte-endothelium interaction in postcapillary venules of the hamster. Am J Physiol 1991;261:H651-H655.

67 Cronstein BN: Adenosine, an endogenous antiinflammatory agent. J Appl Physiol 1994;76:513.

68 Hori M, Kitakaze M: Adenosine, the heart, and coronary circulation. Hypertension 1991;18: 565-574.

69 Downey JM, Liu GS, Thornton JD: Adenosine and the anti-infarct effects of preconditioning. Cardiovasc Res 1993;27:3-8.

70 Murry CE, Jennings RB, Reimer KA: New insights into potential mechanisms of ischemic preconditioning. Circulation 1991;84:442445 .

71 Lawson CS, Downey JM: Preconditioning: State of the art myocardial protection. Cardiovasc Res 1993;27:542-550.
72 Mullane K, Bullough D: Harnessing an endogenous cardioprotective mechanism: Cellular sources and sites of action of adenosine. $\mathrm{J} \mathrm{Mol}$ Cell Cardiol 1995;27:1041-1054.

73 Caldwell-Kenkel JC, Thurman RG, Lemasters JJ: Selective loss of nonparenchymal cell viability after cold ischemic storage of rat livers. Transplantation 1988;45:834-837.

74 Caldwell-Kenkel JC, Currin RT, Tanaka Y, Thurman RG, Lemasters JJ: Reperfusion injury to endothelial cells following cold ischemic storage of rat livers. Hepatology 1989;10:292299.

75 Noack K, Bronk SF, Kato A, Gores GJ: The greater vulnerability of bile duct cells to reoxygenation injury than to anoxia. Implications for the pathogenesis of biliary strictures after liver transplantation. Transplantation 1993;56: 495-500

76 Ikeda T, Yanaga K, Kishikawa K, Kakizoe S, Shimada M, Sugimachi K: Ischemic injury in liver transplantation: Difference in injury sites between warm and cold ischemia in rats. Hepatology 1992;16:454-461.

77 Liu GS, Thornton J, Van Winkle DM, Stanley AW, Olsson RA, Downey JM: Protection against infarction afforded by preconditioning is mediated by $\mathrm{A} 1$ adenosine receptors in rabbit heart. Circulation 1991;84:350-356.

78 Schulz R, Rose J, Post H, Heusch G: Involvement of endogenous adenosine in ischaemic preconditioning in swine. Pflügers Arch 1995; 430:273-282.

79 Auchampach JA, Gross GJ: Adenosine A1 receptors and, K-ATP channels, and ischemic preconditioning in dogs. Am J Physiol 1993; 264:H1327-H1336.

80 Walker DM, Walker JM, Pugsley WB, Pattison CW, Yellon DM: Preconditioning in isolated superfused human muscle. J Mol Cell Cardiol 1995;27:1349-1357.

81 Cave AC, Collis CS, Downey JM, Hearse DJ: Improved functional recovery by ischaemic preconditioning is not mediated by adenosine in the globally ischaemic isolated rat heart. Cardiovasc Res 1993;27:663-668.

82 Lasley RD, Anderson GM, Mentzer RM: Ischaemic and hypoxic preconditioning enhance postischaemic recovery of function in the rat heart. Cardiovasc Res 1993;27:565-570.

83 Liu Y, Ytrehus K, Downey JM: Evidence that translocation of protein kinase $\mathrm{C}$ is a key event during ischemic preconditioning of rabbit myocardium. J Mol Cell Cardiol 1994;26:661668.

84 Brooks G, Hearse DJ: Role of protein kinase C in ischemic preconditioning: Player or spectator? Circ Res 1996;79:627-630.

85 Simkhovich BZ, Przyklenk K, Kloner RA: Role of protein kinase $\mathrm{C}$ as a cellular mediator of ischemic preconditioning: A critical review. Cardiovasc Res 1998;40:9-22.

86 Baines CP, Liu GS, Birincioglu M, Critz SD, Cohen MV, Downey JM: Ischemic preconditioning depends on interaction between mitochondrial KATP channels and actin cytoskeleton. Am J Physiol 1999;276:H1361-H1368.
87 Pain T, Cohen MV, Downey JM: The mitochondrial KATP channel may be a trigger rather than the end-effector of preconditioning's anti-infarct effect. Circulation 1999; 100(suppl I):I-342.

88 Rouse J, Cohen P, Trigon S, et al: A novel kinase cascade triggered by stress and heat shock that stimulates MAPKAP kinase-2 and phosphorylation of the small heat shock proteins. Cell 1994;78:1027-1037.

89 Morgan EN, Boyle EM, Yun W, et al: An essential role for NF-kappa B in the cardioprotective response to ischemia. Ann Thorac Surg 1999;68:377.

90 Xuan YT, Tang XL, Qiu Y, et al: Biphasic response of cardiac NO synthase isoforms to ischemic preconditioning in conscious rabbits. Am J Physiol 2000;279:H2360.

91 Tissieres A, Mitchell HK, Tracy UM: Protein synthesis in salivary glands of Drosophila melanogaster: Relation to chromosome puffs. J Mol Biol 1974;84:389-398.

92 Ryan AJ, Flanagan SW, Moseley PL, Gisolfi $\mathrm{CV}$ : Acute heat stress protects rats against endotoxin shock. J Appl Physiol 1992;73: 1517-1522.

93 Hotchkiss R, Nunnally I, Lindquist S, Taulien J, Perdrizet G, Karl I: Hyperthermia protects mice against the lethal effects of endotoxin. Am J Physiol 1993;265:R1447R1457.

94 Saad S, Kanai M, Awane M, et al: Protective effect of heat shock pretreatment with heat shock protein induction before hepatic warm ischemic injury caused by Pringle's maneuver. Surgery 1995;118:510-516.

95 Terajima H, Enders G, Thiaener A, et al: Impact of hyperthermic preconditioning on postischemic hepatic microcirculatory disturbances in an isolated perfusion model of the rat liver. Hepatology 2000;31:407-415.

96 Terajima H, Thiaener A, Hammer C, Messmer K, Yamamoto Y, Yamaoka Y: Attenuation of hepatic microcirculatory failure during in situ xenogeneic rat liver perfusion by heat shock preconditioning. Transplant Proc 2000;32:1111.

97 Moseley PL: Heat shock proteins: A broader perspective. J Lab Clin Med 1996;128:233234.

98 Clemens MG: Nitric oxide in liver injury. Hepatology 1999;30:1-5.

99 Koo A, Komatsu H, Tao G, Inoue M, Guth $\mathrm{PH}$, Kaplowitz N: Contribution of no-reflow phenomenon to hepatic injury after ischemiareperfusion: Evidence for a role for superoxide anion. Hepatology 1992;15:507-514.

100 Shibayama Y, Nakata K: Role of septal fibrosis in development of hepatic circulatory disturbance in the presence of liver cell enlargement. Liver 1992;12:84-89.

101 Harbrecht BG, Billiar TR, Stadler J, et al: Inhibition of nitric oxide synthesis during endotoxemia promotes intrahepatic thrombosis and an oxygen radical-mediated hepatic injury. J Leukoc Biol 1992;52:390-394. 
102 Niu X-F, Smith CW, Kubes P: Intracellular oxidative stress induced by nitric oxide synthesis inhibition increased endothelial cell adhesivity for neutrophils. Circ Res 1994;74: 1133-1140.

103 Jaeschke H, Smith CW, Clemens MG, Ganey PE, Roth RA: Mechanisms of inflammatory liver injury: Adhesion molecules and cytotoxicity of neutrophils. Toxicol Appl Pharmacol 1996;139:213-226.

104 Rockey DC, Chung JJ: Inducible nitric oxide synthase in rat hepatic lipocytes and the effect of nitric oxide on lipocyte contractility. J Clin Invest 1995;95:1199-1206.

105 Harbrecht BG, Wu B, Watkins SC, Billiar TR, Peitzman AB: Inhibition of nitric oxide synthesis during severe shock but not after resuscitation increases hepatic injury and neutrophil accumulation in hemorrhaged rats. Shock 1997;8:415-421.

106 Rakhit RD, Edwards JR, Marber MS: Nitric oxide, nitrates and ischaemic preconditioning. Cardiovasc Res 1999;43:621-627.

107 Nandagopal K, Dawson TM, Dawson VL: Critical role for nitric oxide signalling in cardiac and neuronal ischemic preconditioning and tolerance. J Pharmacol Exp Ther 2001; 297:474-478.

108 Lochner A, Marais E, Genade S, Moolman JA: Nitric oxide: A trigger for classic preconditioning? Am J Physiol Heart Circ Physiol 2000;279:H2752-H2765.
109 Parratt J: Protection of the heart by ischaemic preconditioning: Mechanisms and possibilities for pharmacological exploitation. Trends Pharmacol Sci 1994;15:19-25.

110 Roth E: The impact of $L$-arginine-nitric oxide metabolism on ischemia/reperfusion injury. Curr Opin Clin Nutr Metab Care 1998;1:9799.

111 Kohli V, Selzner M, Madden JF, Bentley RC, Clavien PA: Endothelial cell and hepatocyte deaths occur by apoptosis after ischemiareperfusion injury in the rat liver. Transplantation 1999;67:1099-1105.

112 Gao W, Bentley RC, Madden JF, Clavien PA: Apoptosis of sinusoidal endothelial cells is a critical mechanism of preservation injury in rat liver transplantation. Hepatology 1998; 27:1652-1660.

113 Kim Y-M, Kim T-H, Chung H-T, Talanian RV, Yin X-M, Billiar TR: Nitric oxide prevents tumor necrosis factor alpha-induced rat hepatocyte apoptosis by the interruption of mitochondrial apoptotic signaling through snitrosylation of caspase-8. Hepatology 2000; 32:770-778.

114 Miller DG: The role of caspase family of cysteine proteases in apoptosis. Semin Immunol 1997;9:35-39.

115 Yang J, Liu X, Bhalla K, et al: Prevention of apoptosis by Bcl-2: Release of cytochrome c from mitochondria blocked. Science 1997; 275:1129-1132.

116 Kim YM, Talanian RV, Billiar TR: Nitric oxide inhibits apoptosis by preventing increases in caspase-3-like activity via two distinct mechanisms. J Biol Chem 1997;272: 31138-31148.
117 Genaro AM, Hortelano S, Alvarez A, Martinez C, Bosca L: Splenic B lymphocyte programmed cell death is prevented by nitric oxide release through mechanisms involving sustained Bcl-2 levels. J Clin Invest 1995;95: 1884-1890.

118 Kim Y, de Vera ME, Watkins SC, Billiar TR: Nitric oxide protects cultured rat hepatocytes from tumor necrosis factor-alpha-induced apoptosis by inducing heat shock protein 70 expression. J Biol Chem 1997;272:14021411.

119 Belghiti J, Noun R, Zante E, Ballet T, Sauvanet A: Portal triad clamping or hepatic vascular exclusion for major liver resection: A controlled study. Ann Surg 1996;224:155-161.

120 Man K, Fan ST, Ng IO, Lo CM, Liu CL, Wong J: Prospective evaluation of Pringle maneuver in hepatectomy for liver tumors by a randomized study. Ann Surg 1997;226: 704-713.

121 Belghiti J, Noun R, Malafosse R, et al: Continuous versus intermittent portal triad clamping for liver resection: A controlled study. Ann Surg 1999;229:369-375.

122 Lemasters JJ, Bunzendahl H, Thurman RG: Reperfusion injury to donor livers stored for transplantation. Liver Transpl Surg 1995;1: 124-138.

123 Blankensteijn JD, Terpstra OT: Liver preservation: The past and the future. Hepatology 1991;13:1235-1250. 